\title{
Estilo de aprendizaje, materiales en múltiples modalidades sensoriales, neurociencia, neuromito
}

\section{Teaching according to the learning style: the neuromyth we must uproot}

\author{
Nadia Mercedes Mendieta Villalba ${ }^{1}$ \\ nmendieta@ups.edu.ec \\ Jorge Humberto Tapia Celi ${ }^{1}$ \\ jorge.tapiac@ug.edu.ec \\ Carlos Valle Navarro ${ }^{1}$ \\ carlos.vallen@ug.edu.ec \\ María Leonor Tobar Bohorquez ${ }^{1}$ \\ maria.tobarb@ug.edu.ec
}

\begin{abstract}
RESUMEN
La neurociencia ha cambiado radicalmente la comprensión de cómo aprende el cerebro y los procesos de aprendizaje-enseñanza en el aula. Un nuevo enfoque es el de un maestro que facilita el aprendizaje con materiales curriculares para múltiples modalidades sensoriales, con el propósito de una interconexión integral de los hemisferios cerebrales del estudiante. Sin embargo, todavía existe la creencia falsa persistente o neuromito de que el estudiante aprende mejor si la información recibida está de acuerdo con su estilo de aprendizaje. La presente investigación demostró que el nuevo alcance de la neurociencia es correcto. A través de la experimentación, el desempeño académico de dos grupos en el curso de 70 nivel de Estrategias de Manufactura, para la carrera de Ingeniería Industrial para el período 48 en la Universidad Politécnica Salesiana en Guayaquil. La prueba de Barsch se aplicó a los estudiantes del primer grupo de 6701 estudiantes para clasificarlos de acuerdo con sus preferencias de aprendizaje sensorial e identificar sus estilos preferidos menos especiales para reforzarlos. No se hizo nada para el segundo grupo de 6760 estudiantes. Además, durante las clases se aplicaron materiales para múltiples modalidades sensoriales y técnicas grupales de enseñanza-aprendizaje para ambos grupos. Finalmente, se ha demostrado que no es necesario detectar la modalidad sensorial que mejor se adapta al aprendizaje del alumno, lo más importante es que el maestro recurra a los mejores materiales que puede diseñar, planificar o preparar para impartir el curso y para reforzar el estilo de aprendizaje menos preferido por el alumno.
\end{abstract}

\footnotetext{
${ }^{1}$ Docente de la Universidad Politécnica Salesiana. Ecuador
}

Revista científica Ciencia y Tecnología Vol 18 No 18 págs. $67-80$ http://cienciaytecnologia.uteg.edu.ec 


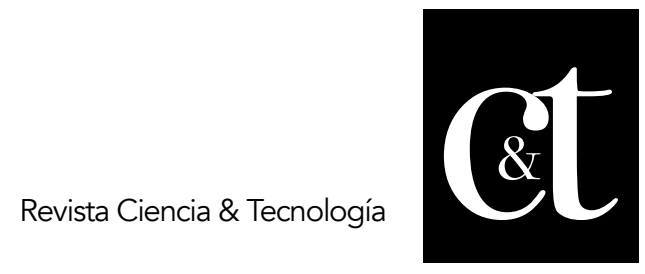

No. 18, 30 de abril de 2018

ISSN impreso: 1390 - 6321

Palabras clave: Estilo de aprendizaje, materiales en múltiples modalidades sensoriales, neurociencia, neuromito

\begin{abstract}
Neuroscience has radically changed the understanding of how the brain learns and the learning-teaching processes in the classroom. A new approach is that of a teacher who facilitates the learning with curricular materials for multiple sensory modalities, with the purpose an integral interconnection of the student's brain hemispheres. However, there still is the persisting false belief or neuromyth that the student learns better if the information received is according to his learning style. The present research proved that the new reach of neuroscience is right. Through experimentation, the academic performance of two groups in the 7th-level course Manufacture Strategies, for the career of Industrial Engineering for the period 48 at the Polytechnic Salesian University in Guayaquil. The Barsch Test was applied to the students of the first group of 6701 students to classify them according to their sensory learning preference and to identify their least preferred styles in order to reinforce them. Nothing was done for the second group of 6760 students. Additionally, materials for multiple sensory modalities and teaching-learning group techniques were applied for both groups during the classes. Finally, it has been proven that it is not necessary to detect the sensory modality that best adapts to the student's learning, what is most important is that the teacher resorts to the best materials he can design, plan or prepare to teach the course in question and to reinforce the learning style least preferred by the student.
\end{abstract}

Keywords: Learning style, materials in multiple sensory modalities, neuroscience, neuromyth

\title{
Introduction
}

At the start of the XXI century, big discoveries were made in the field of neuroscience, in relation to how the brain learns, this causes the teachers to be aware of how they can stimulate changes in the brains of their students, require the knowledge of learning styles and types of intelligence of the students so as to allow the teachers to implement strategies, adapt modern teaching techniques and structures that activate the access doors, favor the knowledge intake and create a range of educative experiences. However, for the employment of these new advances it is needed to leave behind some predetermined ideas, the so called neuromyths of traditional education. Among the most heavily rooted neuromyths in the Ecuadorian educative praxis is the false belief that the students learn better when the information they receive is consistent with their preferred learning style, whether this is visual, auditory or kinesthetic, as it is thought that the students interpret the transmitted information in a more efficient manner. However, the latest neuroscience research shows the opposite, the students learn best when the teacher uses integrated sensory modalities (Guillén \& Ligioiz, 2015).

The physiology of the brain

The human brain has the shape of a nut and the size of a small grapefruit, its weight, for adults, is of approximately 3 kilograms. It is found inside the skull and covered in protective membranes. It is located at the top of the spinal column. It is constantly 


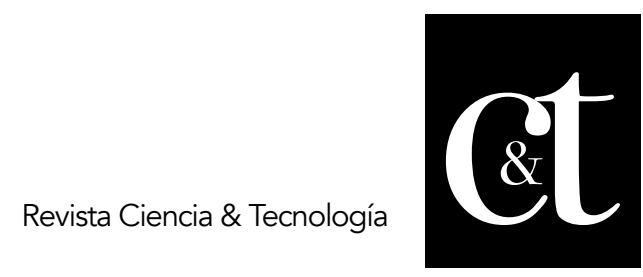

No. 18, 30 de abril de 2018

ISSN impreso: 1390 - 6321

working, even during sleep. Even though it represents just a $2 \%$ of the whole-body weight, it consumes a $20 \%$ of its calories (Sousa, 2014).

\section{Brain Hemispheres}

If we look at the human brain, we can see its structure is composed by two hemispheres, the right and left. The left brain is more structured and the right one is more artistic and emotional. A person with a predominance of the left one will tend to select analytical professions such as engineering, accountant or mechanic. On the other hand, a predominance of the right hemisphere is found on the poet, actors, clowns, painters, among others (Casafont, 2012). In most of the population, the left brain is more dominant because most people are right-handed in their motor function; however, the brain has other functions besides its motor ones. Table 1 synthesizes the so-called hemispheric dominance (Casafont, 2012) and figure 1 exposes the functions of every part of the brain.

\section{Table 1. Hemispheric Dominance}

\begin{tabular}{|c|c|}
\hline LEFT BRAIN & RIGHT BRAIN \\
\hline Analytical thought & Creative thought \\
\hline $\begin{array}{l}\text { Processes language, sensitive to its content. Conscious } \\
\text { language comprehension. }\end{array}$ & $\begin{array}{l}\text { Sensible to tone of voice, volumen and sound direction. } \\
\text { Sensible to language context. } \\
\text { Non-verbal communication. }\end{array}$ \\
\hline Analytical & $\begin{array}{l}\text { Processes the information in a global manner. Relation with } \\
\text { tasks that imply comparisons. Processing of faces. }\end{array}$ \\
\hline $\begin{array}{l}\text { Arithmetic, plannifyier. } \\
\text { Musical rythms. } \\
\text { Structurated, organizer, } \\
\text { rational. }\end{array}$ & $\begin{array}{l}\text { Creative. Intuitive. } \\
\text { Relation to tones and melodies. } \\
\text { Artistic. Imaginative. } \\
\text { Visualizer }\end{array}$ \\
\hline Relación con el consciente. & Relación con el inconsciente. \\
\hline
\end{tabular}

Source: Casafont (2012)

Fuente: Elaboración propia 
Anatomy and Functional Areas of the Brain
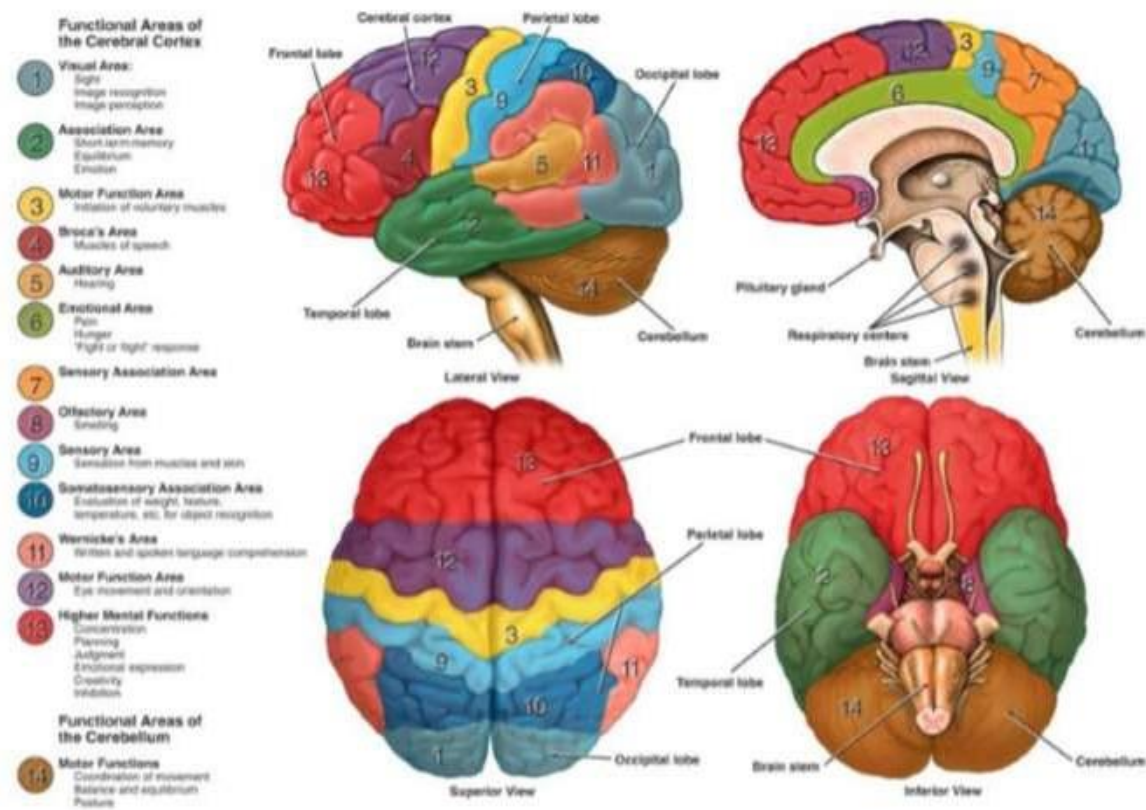

Figure 1. Anatomy and Functional Areas of the Brain

Source:

(https://cdn2.hubspot.net/hubfs/3356070/Imported_Blog_Media/neuroanatomy_large1.jpg? $\mathrm{t}=1515077656273$ )

\section{Learning modalities}

The learning modalities are the sources of sensory information, that can be the ears (auditory), eyes (visual-verbal and visual-iconic) or the hands (Kinesthetic) (Sousa, 2014).

Auditory learning: it originates when the information is listened, this is the case for magistrate classes, movies, seminaries, reduced group work, debates or any information heard by the individual (Sousa, 2014).

Some students with auditory preference do not take notes in class because they get distracted and do not listen. They need to pay attention to what the teacher says, but find themselves focused on the sounds. Sometimes, when there is silence, they move their lips because, mentally, they elaborate sounds to capture the information, learn in groups and benefit with the cooperative learning (Le Fever, 2003).

Verbal-visual learning: It is produced when the information is read. Among the sources of this kind of learning are books, pamphlets, information written on the blackboard, slideshows or any other source in which the person reads (Sousa, 2014). When the students with visual preference listen to a class, suddenly, they look at the empty space to get their minds to visualize what the teacher explains (Le Fever, 


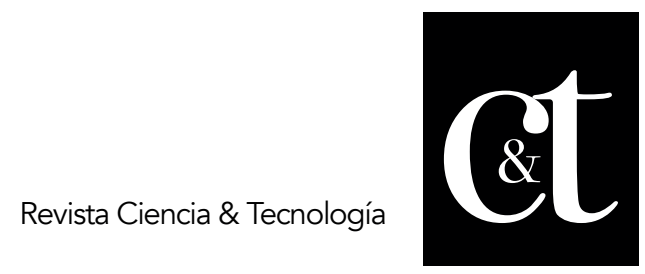

No. 18, 30 de abril de 2018

ISSN impreso: 1390 - 6321

2003).

Visual-iconic learning: It is obtained when the information is seen; however, words do not have a relevant role in the presentation of information. This is the case of graphics, tables, curves, pictures, representations, videos or any other source in which the person sees the information presented under the aspect of a picture or graphic (Sousa, 2014).

Kinesthetic learning: It is produced when the information is manipulated. Sources of kinesthetic information comprise lab exercises, taking notes, performing a research or any other event in which the individual is doing something with a material (Sousa, 2014). The student with a kinesthetic preference needs to move to learn, can't be seated or quiet when the activity assigned to them do not include the use of their hands (Le Fever, 2003). It is worth noting that the human brain has the capacity to change the learning style every day and even every hour, depending on the circumstances of the student. It is common for teachers to prepare the class considering that the students learn in a manner similar to that of themselves, but the truth is that there is no single learning style that works for everyone. If we desire a good learning and retention process, we require of the use of strengths of both brain hemispheres and it is convenient that the students have tasks which include varied elections in each learning style (Taylor \& Lamoreaux, 2008). The Barsch Test is test that allows to identify the learning style of the students (Guillen \& Ligioiz, 2015). In the aspect of engineering teaching, the Felder-Silverman model approaches three approaches: "The aspects of the learning style that it is significant for the engineering education, the styles of learning preferred by the students and the most favored styles of teaching by the teachers and the strategies that will get to the students whose learning styles are not approached by the teaching methods of normal engineering". Felder and Silverman define four dimensions of the learning style: sensorial and intuitive students, visual and verbal students, active and reflexive students, and sequential and global students (Felder \& Silverman, 1988).

\section{Multiple intelligence theory}

Howard Gardner, doctor in social psychology by Harvard University, defines intelligence as the ability to solve problems or create valuable products in one or more cultures. Human beings are born with potentialities marked by genetics, but these are to be developed one way or another depending on the environment, experiences, education, etc. In 1983, Gardner revolutionized teaching thanks to his book about multiple intelligences Frames of Mind (Gardner, 1983). Gardner proposes that the human brain has eight different points where different intelligences could fit; he called them multiple intelligences, and these are: linguistic or verbal intelligence, arithmetic-logical, spatial, musical, corporal and kinesthetic, naturalist, intrapersonal and interpersonal (Antunes, 2000). Larsen-Freeman describes it thus: "verbal linguistic intelligence is the ability to use language in an effective manner. Arithmeticlogical is the ability to think rationally. Spatial-visual intelligence is the ability to locate oneself in the surroundings. Musical- rhythmical is the ability to recognize tone models and rhythm sensibility. Kinetic-corporal is the ability to have one's body wellcoordinated and to be able to use it to express oneself. Intrapersonal intelligence is the ability to understand oneself and apply one's own talent successfully. 


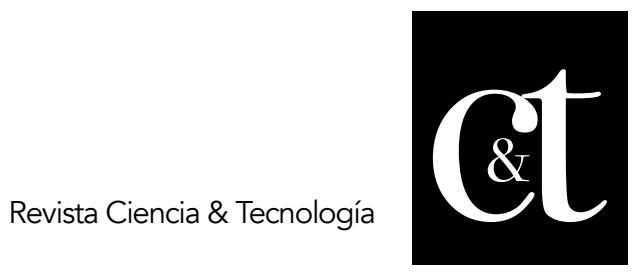

No. 18, 30 de abril de 2018

ISSN impreso: 1390 - 6321

Interpersonal intelligence comprises the ability to work well with others and be able to understand their moods and feelings. Naturalist intelligence is the ability to "understand and organize patterns in nature" (Larsen-Freeman, 2000). In 1995 Goleman associated spiritual intelligence and existentialism under the name of "emotional intelligence, which is the ability to comprehend emotions in oneself and others" (Goleman, 1995).

In this context, the discovery of multiple intelligences presents itself as a viable and effective alternative for the development of the abilities of human beings, not only cognitive but also motor, emotional, etc. This is very necessary for the processing of information and the finding of different abilities that a person can develop and constitute different ways of perceiving reality, as well as the manifestation of several learning styles that combine in an individual. One of the forms with which multiple intelligences can be stimulated is with Kagan structures which are forms of configuring the interaction of students in relation to any content. They are applied to encourage personality, cooperation, high-level thinking and others. With the Kagan structures the students learn to appreciate the singularity and contributions from other students, that is why its use creates a general change of the social character (Kagan, 2003).

\section{How the brain learns better?}

Multisensory processes. If information enters the brain through two or more combined sensory modalities, along with emotion, then learning will occur more easily and retention will be better. When working with a difficult topic the brain learns better with an abundant sensory stimulation (Taylor \& Lamoreaux 2008). Predictable sequence. Five steps are required for an optimum learning: -Preparation, when the brain is shown the way the process is going to develop, immediately creates a conceptual map and prepares to form possible connections. -Acquisition, the brain receives information directly through writings, analytical plans, determined readings and, indirectly, with visual materials and multimedia. The students must be exposed to different options of preferred learning styles (visual, auditory, kinesthetic). Elaboration, in this the amendment of errors and mistakes is undertaken. The brain analyzes the topics through explicit methods (reading, listening, discussing, filling work papers) and implicit methods (imitations, dramatization, life experience) (Taylor \& Lamoreaux, 2008).

Memory formation with a number of connections that allow the information to be codified in the long-term memory so it can be remembered later on. -Finally, the functional integration in which the neurons communicate and fire together enough times to create connections with the purpose of allowing the information to be evoked and applied in diverse situations. Emotions help make the learning long-term just as consecutive revisions help recovering and retention (Taylor \& Lamoreaux, 2008). Flexible environment. As every brain is unique it is necessary that the learning environment be flexible; for instance, variations in the arrangement of chairs in a circle, in U-shape, etc. Some students prefer reclined positions or to remain standing. Teachers must allow the choosing of positions in which the students can sit and plan activities that encourage them stand, move and stretch frequently. Intrinsic motivation. It is required to help the creativity of the student, to create a high self- 


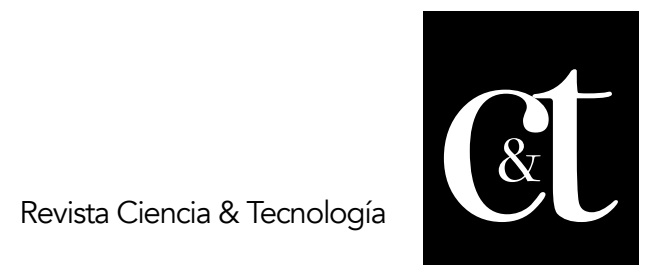

No. 18, 30 de abril de 2018

ISSN impreso: 1390 - 6321

esteem level and reflexive thinking (Taylor \& Lamoreaux, 2008).

\section{Scientific studies}

Among the relevant tests to determine the incidence of learning styles in the academic performance of the students, the following can be cited: The research of Krätzig and Arbuthnott in 2006 in which they helped 65 college students. In this study it was determined the correlation between the learning style preference and performance in the memory tests, related to sensory modalities: visual, auditory and kinesthetic (Krätzig \& Arbuthnott, 2006). Experiments with a multisensory focus were also performed by Massa and Mayer in 2006 with college students and adults with no college education. The results did not back up the fact that the students had to receive differentiated teachings in the multimedia environment (Massa \& Mayer, 2006). In the year 2009 a research was carried out in the Education Faculty of the Mayor National University of Saint Mark in Peru (Universidad Nacional Mayor de San Marcos) in Peru, to 40 students of the fifth semester in the daytime turn. Through the analysis of the correlation different relations between multiple intelligences, learning styles and performance levels were found (Jiménez, Díaz, Villegas, \& Sánchez, 2009). In Spain an investigation was performed in the edition course 2010-2011 of the Master's of High-school Teacher's Formation offered by the Education Faculty of the University of Cantabria, its use and benefits of the activities in the high-school English classrooms that take into account the learning styles of the students, based on the Theory of Multiple Intelligences with the purpose of improving the learning of this language (Gómez Castro \& Sobremazas Martínez, 2011).

\section{Description of the course of manufacture strategies and general purpose}

The course of Manufacture Strategies is imparted in the career of Industrial Engineering. "It is based in the strategies that can be materialized in a manufacturing system to support and/or drive the competitive positioning of a company. Specifically, it addresses strategies related to the development and design of products, processes and quality". (Salesian Polytechnic University. National Academic System (W) Analytic Plan. Industrial Engineering, Unified Proposal, 2006). Its general purpose is to "study a series of conceptual frameworks, approaches and techniques related to the strategic interpretation of a manufacture system to support and/or conduct the competitive positioning of a company" (Salesian Polytechnic University. National Academic System (W) Analytic Plan. Industrial Engineering, Unified Proposal, 2006).

\section{Methodology}

The methodology was founded on a field research of the descriptive and explicative type applied to the students of the course of Manufacture Strategies for groups 6701 and 6760 and is composed of four parts. In the first part, the students of group 6701 were evaluated and classified according to their score on the Barsch Test of Learning Styles (see Table 2). Additionally, the most frequent learning style was identified in Figure 3 and the style that had the best grades, Figure 4 . In the second part, the classes were given with the use of curricular materials in multiple sensory modalities, such as graphic organizers (see Figure 2) of the references (OrganizadoresGraficos.com) and (Sousa, 2014)). Additionally, work was performed with teaching-learning group techniques of several types, chosen in relation to the topic approached in the course units. 


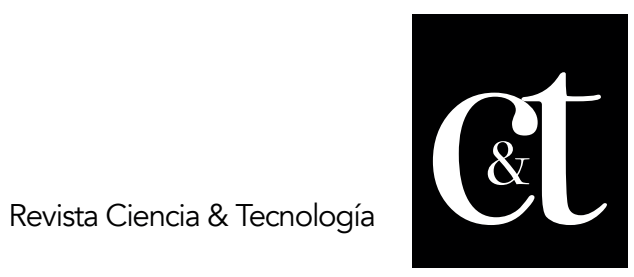

No. 18,30 de abril de 2018

ISSN impreso: 1390 - 6321

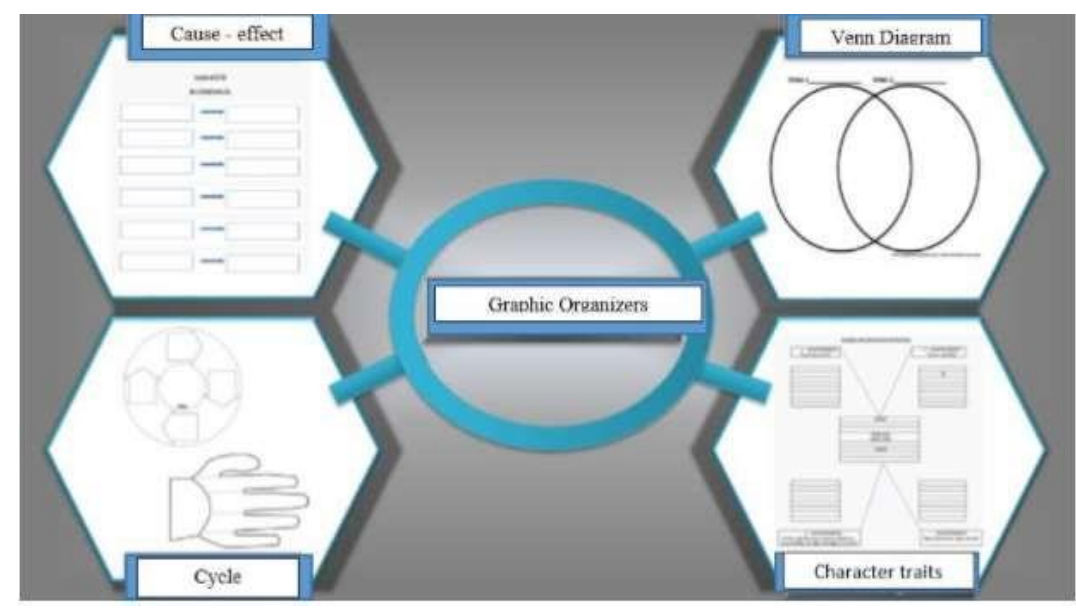

Figure 2. Graphic Organizers

Source: Sousa (2014)

In the third part, a study of state of opinion was performed through an interview, which investigated the opinion of the study population of 23 students from group 6701 in the course of Manufacture Strategies in relation to the employed methodology to determine if the process was satisfactory and reached the results desired by the students and to verify the achievement of the general objective of the analytical plan of the course. Finally, the academic grades of group 6701 were compared to those of group 6760 to evidence he efficiency of the use of materials in different sensory modalities integrated for a better brain learning. Once the information was collected, the data was processed and, with the help of computers, the corresponding statistic graphics.

\section{Results}

Next in Table 2 is presented the results of the Barsch Test of Learning Styles (Misionessim.org). Figure 3 shows the percentages of the course classified according to their sensory learning preference. Figure 4 indicates the learning sensory preference that had a better academic grade in group 6701 . 


\section{Table 2. Results of the Barsch Test of Learning Styles}

\begin{tabular}{|c|c|c|c|c|}
\hline No. & NAME & Visual & Auditory & Kinesthetic \\
\hline 1 & AGILA VILLACIS JONATHAN ANDRES & 30 & 26 & 28 \\
\hline 2 & AMORES SANCHEZ ANTHONY JORDAN & 28 & 22 & 19 \\
\hline 3 & BASTIDAS SINCHE EDGAR MARCELO & 26 & 29 & 19 \\
\hline 4 & BELLO BOLAÑOS MARIO FERNANDO & 32 & 20 & 20 \\
\hline 5 & CACERES TOLEDO JORGE ALEJANDRO & 30 & 28 & 19 \\
\hline 6 & CAICEDO ESCALANTE ALEJANDRA DEL ROCIO & 32 & 24 & 17 \\
\hline 7 & CARCHIPULLA LLANOS RONALD ALEXIS & 36 & 32 & 14 \\
\hline 8 & CASTILLO ARMENDARIZ ODALYS JORLENY & 38 & 21 & 30 \\
\hline 9 & CHANCAY JARAMILLO ANTHONELLA STEFAN & 28 & 28 & 28 \\
\hline 10 & GAVILANEZ PACHECO JORMAN JAVIER & 23 & 13 & 15 \\
\hline 11 & GODOY LUNA IVAN ALEXANDER & 26 & 30 & 30 \\
\hline 12 & KARANOVIC VELEZ DUSKO MILAN & 28 & 27 & 18 \\
\hline 13 & LUNA CABRERA JORDDY HERNAN & 38 & 20 & 22 \\
\hline 14 & LUNA ROMAN JOSELYNE JAZMIN & 18 & 32 & 11 \\
\hline 15 & MORENO GILSE FRANK ANTHONY & 28 & 32 & 22 \\
\hline 16 & OROZCO OROZCO PAOLA DOLORES & 28 & 28 & 22 \\
\hline 17 & PEREZ URRESTO CHRISTIAN OSWALDO & 36 & 38 & 36 \\
\hline 18 & POSLIGUA GARCIA ANDRES EDUARDO & 24 & 26 & 17 \\
\hline 19 & RODRIGUEZ COCHEA EDISON RAUL & 30 & 18 & 22 \\
\hline 20 & RUIZ CAÑOLA JOSE OSWALDO & 32 & 19 & 16 \\
\hline 21 & TAPIA VILLAMAR RONALD AURELIO & 36 & 22 & 22 \\
\hline 22 & VERA CAMPAÑA RICHARD ANDRES & 34 & 30 & 21 \\
\hline 23 & ZUÑIGA VILLAGOMEZ CESAR ALEXANDER & 26 & 32 & 26 \\
\hline
\end{tabular}

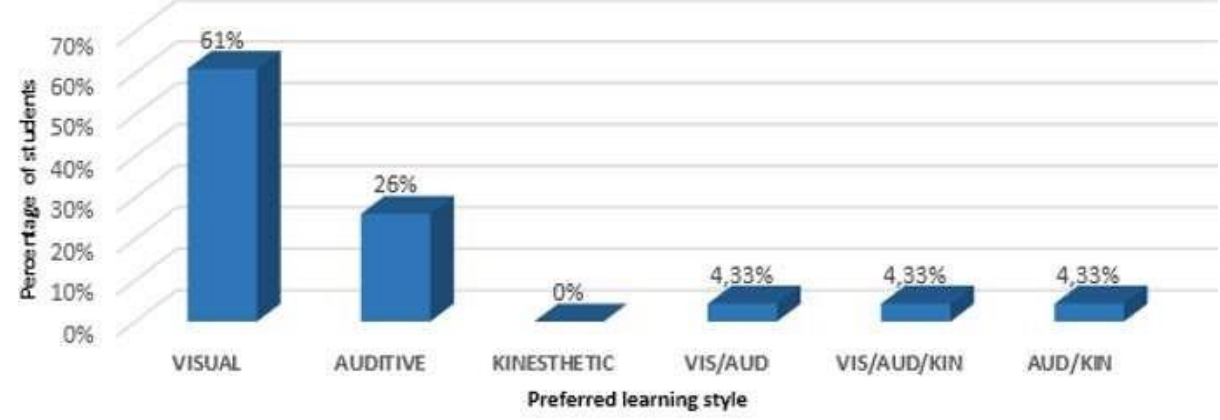

Figure 3. Classification of students according to their preferred learning style

Source: Nadia Mendieta 75 

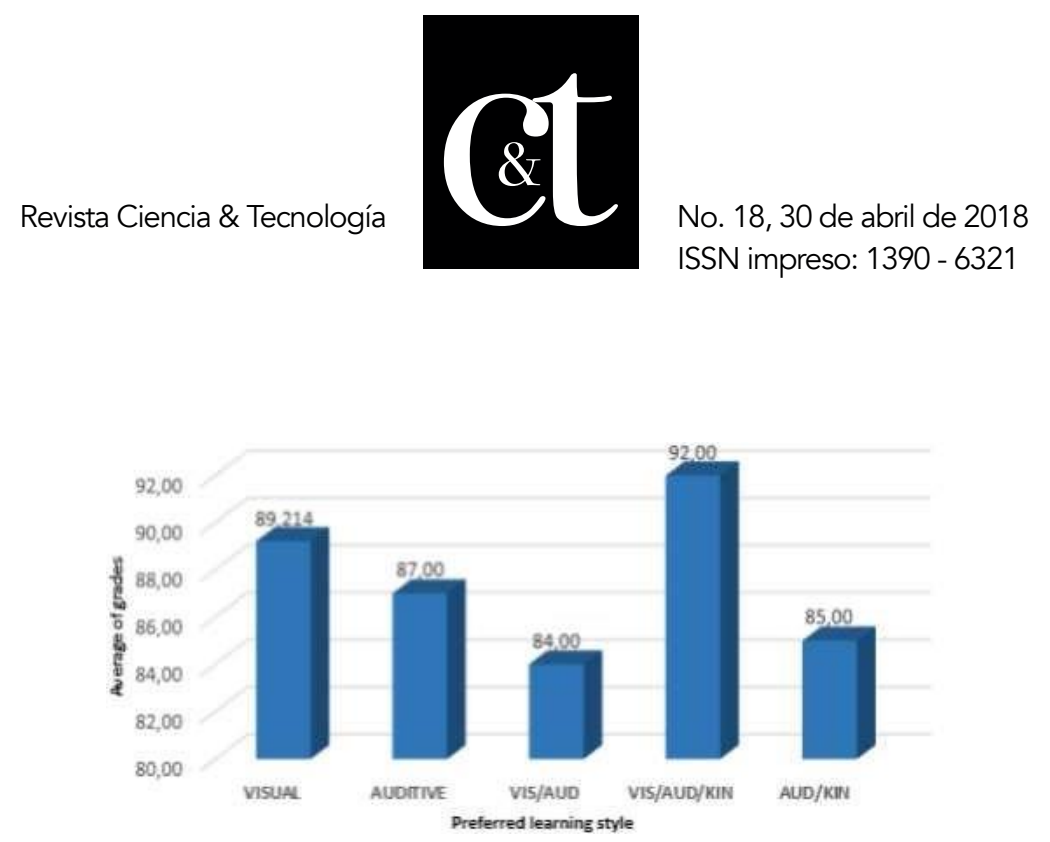

Figure 4. Average of grades vs. Learning styles

Source: Nadia Mendieta

The average grades of the group 6701 were of 88.35 , for the group 6760 the average was of 86.87. Next are six questions that make up the base instrument for the interview applied to the study population of 23 students from group 6701. As shown in each of the graphics, the opinions of each student are also tabulated in relation to the categories: totally, mostly, moderately, a little and nothing.

Question No. 1

Did you understand the conceptual frameworks for the course of Manufacture Strategies related to the strategic interpretation of the manufacture system to support and/or conduct the competitive positioning of the company?

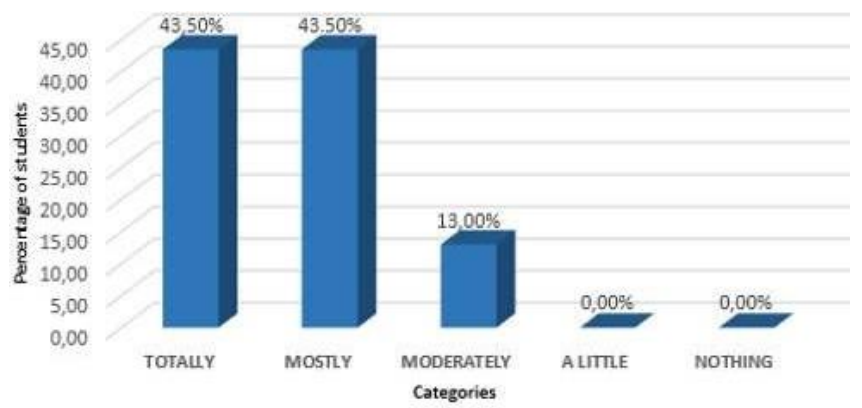

Figure 5. Comprehension of conceptual frameworks

Source: Nadia Mendieta

Question No. 2

Did you understand the focus and technics related to the strategic interpretation of the manufacture system to support and/or conduct the competitive positioning of the company? 


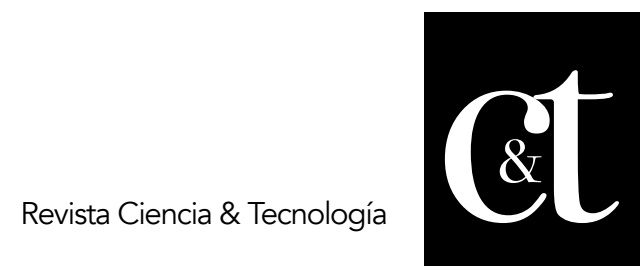

No. 18, 30 de abril de 2018

ISSN impreso: 1390 - 6321

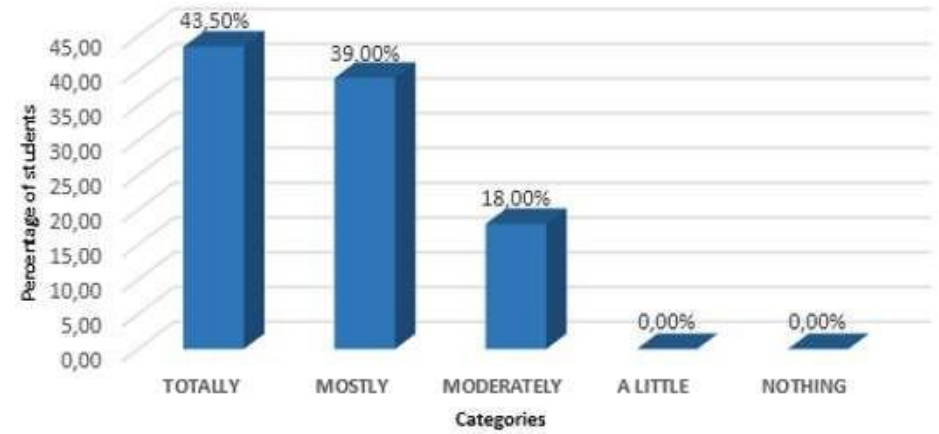

Figure 6. Understanding focus and technics Source: Nadia Mendieta

Question No. 3

Do you believe that the Barsch Test help to identify your preferred learning style and the ones you have to reinforce?

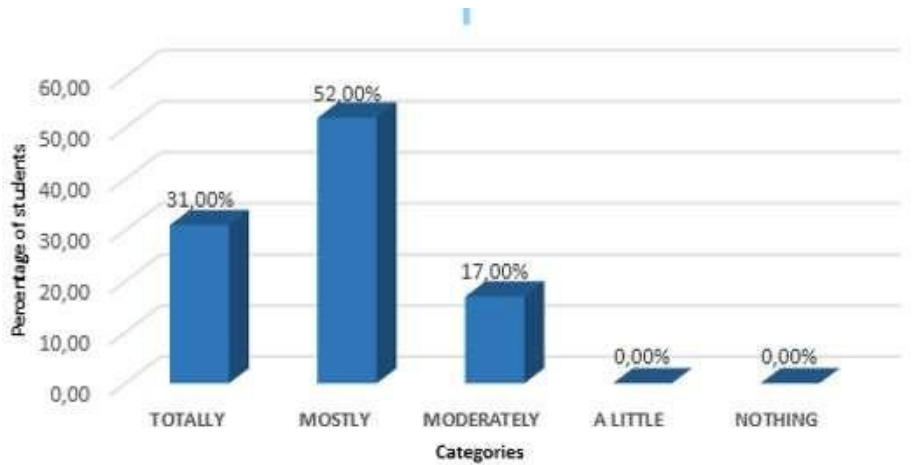

Figure 7. Preferred learning style

Source: Nadia Mendieta

Question No. 4

Do you consider that the use of graphic organizers was a tool in the process of teaching and learning that helped you understand the course of Manufacture Strategies and reinforce your modality and visual learning?

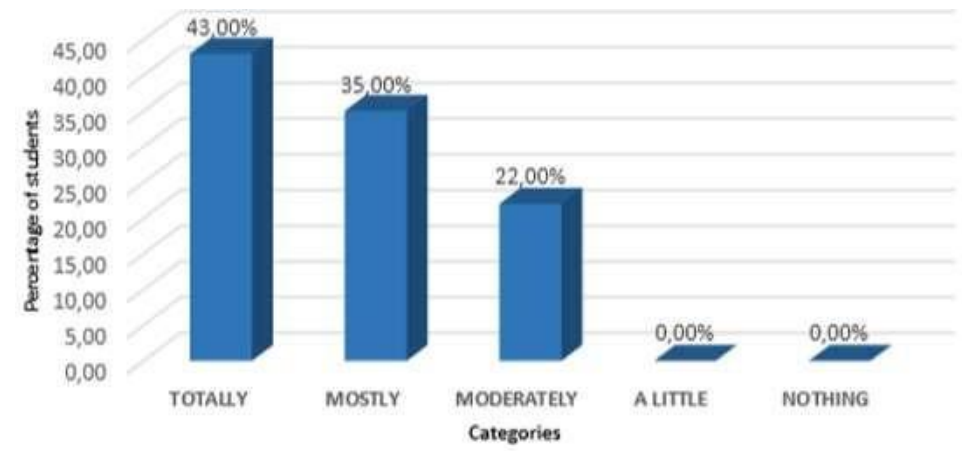

Figure 8. Use of graphic organizers Source: Nadia Mendieta

$$
77
$$




\section{Question No. 5}

Do you consider that the use of teaching-learning group techniques (storm of ideas, debates and forums) were a tool that helped you understand the course Manufacture Strategies and to reinforce your modality of learning through audition?

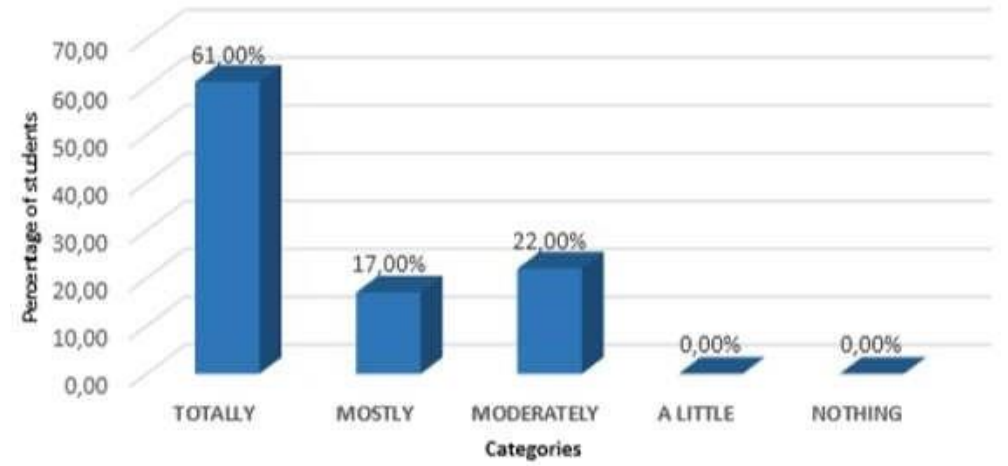

Figure 9. Use of teaching-learning group techniques Source: Nadia Mendieta

Question No. 6

Do you consider that the designation of psychomotor tasks (investigation, quality diagrams and processes diagrams) during the course helped you understand better the course of Manufacture Strategies and to reinforce your kinesthetic learning modality?

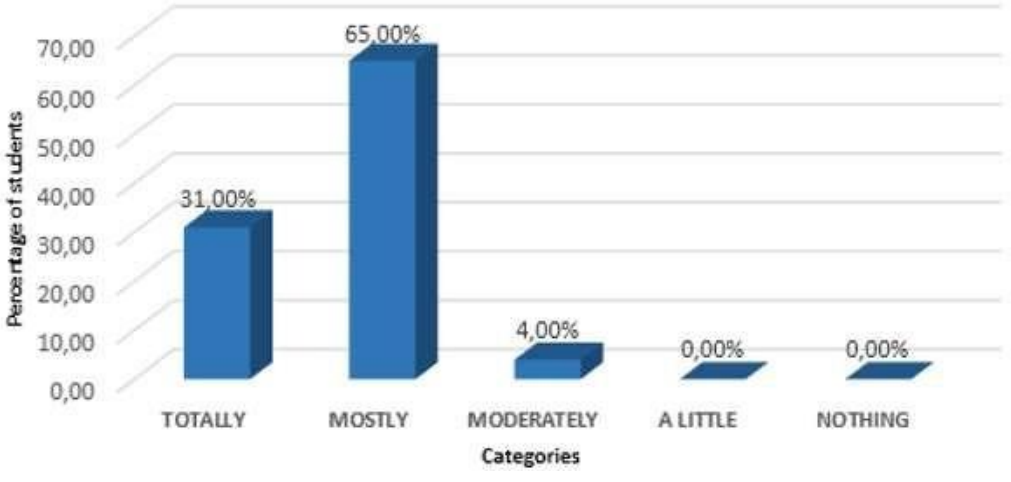

Figure 10. Use of psychomotor tasks

Source: Nadia Mendieta

\section{Discussion}

Figure 3 shows how the $61 \%$ of the students of group 6701 have a tendency to visual learning, so this comprises most of the students. Auditory and kinesthetic modalities were the least frequent. The statistics indicated that the students are not inclined to kinesthetic learning, which got a $0 \%$ of the students; this motivated the group with 


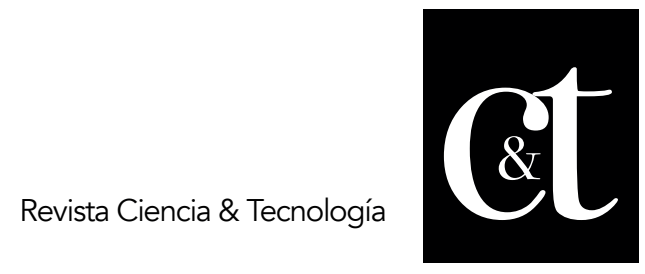

No. 18, 30 de abril de 2018

ISSN impreso: 1390 - 6321

psychomotor works such as: research tasks, use of quality tools, diagrams, graphic designs and calculations, in general, activities in which the students used their hands. Additionally, work with graphic organizers was done to help the students with visual preference, and, to incentivize them, they were made to lead as managers in workshop groups. Auditory sensory preference got a $26 \%$ of the students, so during the teaching-learning process, group techniques were employed such as storms of ideas, debates, oral presentations and video-forums, to improve and reinforce said learning style.

According to what is shown in Figure 4, it was determined that the student with a learning preference that is visual- auditory-kinesthetic simultaneously, got the highest average grade (92), the student in question stood out in different activities; as she counts with three preferred sensory modalities made her learning process more effective. Groups 6701 and 6760 obtained similar close average grades (6701 had 88.35 and 6760 had 86.87 ), which means that the u se of materials in multiple sensory modalities favored the learning of the students in two courses.

Figure 5 indicates that the $87 \%$ of all students in the class completely understand (an in great measure) the conceptual frameworks of the course. This is confirmed in the results from Figure 6 , in which is seen that the $82 \%$ of the students understood the focus and techniques that were related to the strategic interpretation of the manufacture system, which was achieved with the general objective of the course. According to Figure 7, an $83 \%$ of the students consider that the Barsch Test helped them totally and in great measure to identify their preferred learning style. In Figure 8 the $78 \%$ of the students believe that the use of graphic organizers reinforced the visual modality of learning. In Figure 9 the $78 \%$ of the students considers that the teaching-learning group techniques helped them comprehend the course and reinforce their auditory modality and, in Figure 10, the $96 \%$ of the students think that the psychomotor tasks reinforced their kinesthetic learning modality. As such, it is recommended that the teacher observes continuity in the creation, planning and disposition of materials in multiple sensory modalities with the purpose of achieving the brain development of the students and to optimize the teaching and learning in the course.

\section{Conclusion}

The use of materials in multiple sensory modalities favors in the students the brain interconnection. The methodology employed was able to reinforce the learning styles least-preferred by the students and helped in the understanding of the course and, as such, to achieve the general objective of the course.

Considering that the best average grade in group 6701 was achieved by the student who has visual-auditory-kinesthetic preferences simultaneously, it is concluded that it is necessary to develop in the students the three types of learning styles, always reinforcing the least-preferred style, which is feasible because the brain is plastic and continuously modifies its structure in response to experiences, teaching-learning methodologies, materials in multiple sensory modalities and appropriate training. The teacher has a significant role in the brain development of his students which is why, depending on the nature of the course, he must invent, plan and use materials in 


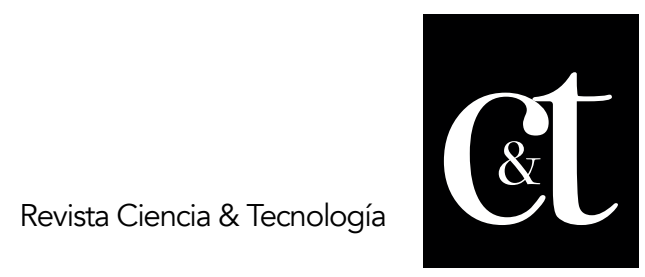

No. 18, 30 de abril de 2018

ISSN impreso: 1390 - 6321

multiple sensory modalities with the end of optimizing the teaching- learning of the course to improve the skills of the student and the quality of education. In the field of education, the false beliefs or neuromyths cannot be suppressed immediately.

However, the teachers can be aware of these changes and progressively replace these opinions with new ideas based on the scientific knowledge of neuroscience.

\section{Bibliographic references}

Antunes, C. A. (2000). Las inteligencias múltiples. Cómo estimularlas y desarrollarlas. Colección para educadores. Madrid: Narcea.

Casafont, R. (2012). Viaje a tu cerebro. Barcelona, España: Ediciones B, S. A.

Felder, R. M., \& Silverman, L. K. (1988). Estilos de aprendizaje y de enseñanza en la educación de ingeniería [Versión electrónica]. Ing. Educación, 78(7), 674-681.

Gardner, H. (1983). Frames of Mind: The theory of Multiple Intelligences. New York: Bantam Books.

Goleman, D. (1995). Emotional Intelligence. New York: Bantam Books.

Gómez Castro, C., \& Sobremazas Martínez, C. (2011). Multiple Intelligences and Learning Styles in the Teaching of English: A Study Case. Ed. Interfacultativo, 111.

Guillén, J. C., \& Ligioiz, M. (2015). Neuromitos en educación. El aprendizaje desde la neurociencia. Barcelona, España: Plataforma Editorial.

Jiménez, E. J. B., Díaz, I. M., Villegas, J. V., \& Sánchez, T. C. (2009). Las inteligencias múltiples, los estilos de aprendizaje y el nivel de rendimiento. Investigación Educativa, 13(23), 9-20. JOUR.

Kagan, S. (2003). Breve historia de las Estructuras Kagan. Kagan Online Magazine.

Krätzig, G. P., \& Arbuthnott, K. D. (2006). Perceptual learning style and learning proficiency: A test of the hypothesis. Journal of Educational Psychology, 98(1), 238-246. JOUR. https://doi.org/10.1037/0022-0663.98.1.238

Larsen-Freeman, D. (2000). Techniques and Principles in Language teaching. Oxford: Oxford.

Le Fever, M. D. (2003). Estilos de Aprendizaje. Cómo enseñar a cada uno de los que Dios nos confió. Miami: Editorial Patmos.

Massa, L. J., \& Mayer, R. E. (2006). Testing the ATI hypothesis: Should multimedia instruction accommodate verbalizer-visualizer cognitive style?

Sousa, D. ed. (2014). Educational Neuroscience. Corwin Press.

Taylor, K. \& Lamoreaux, A. (2008). Teaching with the brain in mind. New directions for adult \& continuing education, Vol 2008, Issue 119: 45-59. 